\title{
Correction to: Important juvenile manta ray habitat at Flower Garden Banks National Marine Sanctuary in the northwestern Gulf of Mexico
}

\author{
Joshua D. Stewart ${ }^{1,2} \cdot$ Marissa Nuttall $^{3,4} \cdot$ Emma L. Hickerson $^{3} \cdot$ Michelle A. Johnston $^{3}$ \\ Published online: 30 August 2018 \\ ○) Springer-Verlag GmbH Germany, part of Springer Nature 2018
}

\section{Correction to: Marine Biology (2018) 165:111 https://doi.org/10.1007/s00227-018-3364-5}

In a recent paper (Stewart et al. 2018), we reported on the presence of juvenile manta rays in the Flower Garden Banks National Marine Sanctuary (FGBNMS) and suggested that the region serves as a nursery habitat for the species. Unfortunately we failed to consider the Masters thesis by Jeffrey N Childs (2001) entitled: 'The occurrence, habitat use, and behavior of sharks and rays associating with topographic highs in the Northwestern Gulf of Mexico'. Childs (2001) was the first to document the presence of juvenile manta rays at the Flower Garden Banks and he suggested that the Flower Garden Banks serve as a nursery habitat for juvenile manta rays. We regret this oversight and apologize for failing to acknowledge and cite this relevant work.

Unfortunately we also now realize that a few dive logs belonging to $\mathrm{E}$. Hickerson that were used in our study were also reported in Childs (2001), as sightings made from 1993 to 2001 were voluntarily provided for Childs' thesis by E. Hickerson.

We have modified our publication (Stewart et al. 2018) in order to properly acknowledge the findings of Childs (2001). We kindly ask our readers to consider the following points when reading the manuscript.

The original article can be found online at https://doi.org/10.1007/ s00227-018-3364-5.

Joshua D. Stewart

j8stewart@ucsd.edu

1 Scripps Institution of Oceanography, University of California San Diego, La Jolla, CA, USA

2 The Manta Trust, Dorset, UK

3 NOAA Flower Garden Banks National Marine Sanctuary, Galveston, TX, USA

4 CPC, San Diego, CA, USA
Abstract

The third sentence ('The juvenile stage in particular is virtually unstudied, as juvenile oceanic mantas are rarely observed in the wild and are known primarily from fisheries and captive individuals') should be omitted.

The second last sentence should read as follows: 'Temporal patterns of use and the prevalence of juveniles support the assumption that this region serves as nursery habitat for M. birostris and M. cf. birostris'.

Introduction

Second paragraph, first sentence: 'virtually' should be replaced by 'largely', second sentence 'the only published information' should be 'the majority of published information'.

Last three sentences should read as follows: 'Childs (2001) found that many of the manta rays seen at the Flower Garden Banks are juveniles, and that the banks could serve as a nursery habitat for the species. Here we describe the size distribution of mantas at the Flower Garden Banks National Marine Sanctuary and present evidence of site use by almost exclusively juvenile manta rays based on clasper development. We evaluate the habitat use and temporal visitation of mantas at FGBNMS against three established criteria used to classify elasmobranch nursery areas (Heupel et al. 2007). We suggest that FGBNMS and the surrounding region may represent the first nursery habitat for M. birostris and $M$. $c f$. birostris that follows the Heupel et al. (2007) criteria. We further emphasize the importance of this region to future research on this life stage and regional conservation of these species.

Results and discussion

Page 5, first section, the last sentence should be: 'It is possible that the observed patterns in size frequency may change seasonally, although Childs (2001) recorded juvenile-sized mantas throughout the year including winter'.

Page 6, second paragraph, the third sentence should be: 'Mantas are only occasionally seen feeding at the banks, and they do not appear to visit cleaning stations on the reefs (Childs 2001)'. 
We would also like to add here that Childs (2001) observed mantas foraging at approximately $50 \mathrm{~m}$ at the deep reef interface, which may be indicative of more common deep-water foraging in the region.

Page 6, last six sentences should read as follows: 'Childs (2001) reported sightings of juvenile-sized mantas at Sonnier bank. Additionally, FGBNMS researchers have received multiple reports of mantas at Bright bank, $28 \mathrm{~km}$ east of EFGB. This suggests that other banks in the vicinity of FGBNMS may also be important habitat for juvenile manta rays. This study provides some of the first insights into juvenile habitat use of M. birostris and M. cf. birostris, and confirms the suggestion by Childs (2001) that Flower Garden Banks and surrounding areas in the northern Gulf of Mexico serve as a nursery habitat for juvenile mantas. This information can be used to design management strategies that explicitly protect important regions for different life stages of manta rays in the Gulf of Mexico and Caribbean Sea. Additionally, the prevalence of juvenile mantas at FGBNMS provides an opportunity to gain further insights into this life stage through telemetry studies, stable isotope studies of feeding behavior, and genetic analyses'.

In addition two minor mistakes in the references are corrected: the full citation for Stewart et al. (2017) erroneously omitted the journal (Marine Ecology Progress Series) and is now correctly cited. The full citation for Johnston et al.
(2013) incorrectly reported the number of pages in the report (362 instead of 202) and is now correctly cited.

\section{References}

Childs JN (2001) The occurrence, habitat use, and behavior of sharks and rays associating with topographic highs in the Northwestern Gulf of Mexico. Texas A\&M University. https://oaktrust.libra ry.tamu.edu/handle/1969.1/ETD-TAMU-2001-THESIS-C45. Accessed 4 Aug 2018

Heupel MR, Carlson JK, Simpfendorfer CA (2007) Shark nursery areas: concepts, definition, characterization and assumptions. Mar Ecol Prog Ser 337:287-297. https://doi.org/10.3354/meps337287

Johnston MA, Nuttall MF, Eckert RJ, Embesi JA, Slowey NC, Hickerson EL, Schmahl. GP (2013) Long-term monitoring at the East and West Flower Garden Banks National Marine Sanctuary, 2009-2010, vol 1: technical report. US Dept. of Interior, Bureau of Ocean Energy Management, Gulf of Mexico OCS Region, New Orleans, Louisiana OCS Study BOEM 2013-215

Stewart JD, Rohner CA, Araujo G, Avila J, Fernando D, Forsberg K, Ponzo A, Rambahiniarison JM, Kurle CM, Semmens BX (2017) Trophic overlap in mobulid rays: insights from stable isotope analysis. Mar Ecol Prog Ser 580:131-151. https://doi.org/10.13748 /j.cnki.issn1007-7693.2014.04.012

Stewart JD, Nuttall M, Hickerson EL, Johnston MA (2018) Important juvenile manta ray habitat at Flower Garden Banks National Marine Sanctuary in the northwestern Gulf of Mexico. Mar Biol. https://doi.org/10.1007/s00227-018-3364-5 